\title{
长距离输水管线的设计探究
}

田铭迪

兴安盟水务投资有限责任公司

DOI:10.32629/hwr.v4i1.2715

[摘要] 目前,社会经济快速发展,水资源短缺问题日益突出,水库工程建设数量及规模逐渐扩大,在发展经济用水,改善民生和生态环境方面发 挥重要作用。与此同时,管道输水距离越来越长,合理选用长距离输水管道模式对改变传统分割供水局面,对水资源进行科学合理分配,保障供水 稳定性方面具有决定性作用。因此,对长距离输水管道规划设计进行详细研究具有十分重要的现实意义。

[关键词] 长距离输水; 管线设计; 数量

\section{1 输水管线设计}

1. 1 管线选择原则

首先管线应该在避开公路、铁路、山谷等地质条件恶劣地段的基础上 尽可能地缩短, 并且寻求方便利用重力来进行输水的地形条件。同样要避 免的路段, 还有, 土壤腐蚀性较大的, 地区, 否则金属管道容易遭到腐蚀, 其 次, 永久性管线的铺设要慎重, 尤其是在矿区内进行铺线的时候, 要弄清地 下的结构, 不能在采空区铺设永久性管线。此外, 比较重要的一点就是, 单 位要将经济效益和社会效益结合在一起, 当经济效益和社会效益产生冲突 的时候, 要权衡利弊, 慎重考虑, 例如说当线路需要经过良田的时候, 单位 应做出适当退步, 尽量不占用良田。

\section{2 管材的选择}

管道管线对整个工程来说, 起着决定性的作用, 好的管材能保证管道 的安全输水, 同时, 不同管线材料的选择对工程造价也会产生很大影响。在 选择管材的时候, 我们需要注意许多因素, 将成本预算、投资规模、工程规 模等因素都放在我们考量范围内, 遵守方便施工、保证安全、增加利润的 原则, 根据内压、管径、荷载以及工程地区地质条件, 地形条件等, 设计出 较为全面和科学的设计方案。需要注意的是城市的长距离输水和其他地区 有所区别, 它的管道直径都大于一米。目前来说, 我们常用的管材有预应力 钢筒混凝土管、钢管、预应力钢筋混凝土管、玻璃钢复合管等, 我们在长 距离输水方面应用的最多的还是塑料管和钢管, 当然预应力混凝土管和玻 璃钢管也有所涉及。

接下来我们会对这几种管线材料的各项性能做出适应阐述。铸铁管、 预应力钢筒混凝土管、预应力混凝土管混凝土管以及玻璃钢管的接口形式 都是承插口, 而钢管则是用焊接口。而这其中预应力钢筒混凝土管耐压性 最高, 预应力混凝土管耐压性最低。就耐腐蚀性的性能来说, 从强到弱依次 是预应力混凝土管、预应力钢筒混凝土管、玻璃钢管、钢管以及铸铁管。 一般来说, 预应力混凝土管不能运用在工作压力高的工程中, 而钢管和玻 璃管等适应性良好。综合来说预应力钢筒混凝土管的各项指标较靠前, 因 此它的价格也是诸多材料中最贵的。

\section{3 长距离输水管道的数量}

设计规范对于输水管道有一定的要求, 输水管道最好安排两条或者多 于两条, 另一条管道主要起到一个备用的作用, 这样即使有一条管道出现 了故障, 我们也能及时调整状况, 保证输水的稳定性和安全性。此外, 在计 算连通管和输水干管的管径和连通管根数的时候, 为了保证供水的安全, 我们仍然要假设干管有一段出现问题来考虑。

1. 4 长距离输水管道的通气

在实践考察过程中, 笔者发现许多长距离输水管线不能够正常运行的 原因之一就在于通气不畅, 产生气阻现象, 管道的输水因此也被影响, 所以
我们可以看出管线上的排气阀对管道通气至关重要。在经过一段时期的工 作后, 输水管道常常会因为长距离或其他等原因而积聚气体, 如果不能顺 利排掉气体, 当管道有水要运输的时候, 进水速度随着其他排出的速度而 加快, 这就会带来水压过高的问题, 水锤事故的隐患逐渐被埋下。因此, 单 位应重视排气阀的设置, 排气阀能够帮助排出管道内积聚的气体, 加快通 水, 避免发生水锤。

\section{2 穿越工程}

管道输水具有一定的优势, 在某些情况下可以减小部分障碍物的影响, 但这并不意味着长距离管道输水能够完全避免障碍物的影响, 在遇到公 路、铁路、河流、山峦等障碍物的时候, 我们需要通过穿越工程来继续, 比如说遇到河流时, 我们需要通过倒虹吸或者管桥来跨越, 当工程遇到公 路铁路时, 为了完成输水工程, 也为了提高社会效益不影响交通运输的正 常工作, 我们常采用顶管加套管的方法来实现穿越。在进行穿越工程时, 我们要注意工程的安全性, 适当增加管的厚度, 避免对一些公共设施造成 损伤。但总的来说, 穿越工程是一项较耗费财力、物力的工程, 如果能够在 设计方案的过程中省去穿越工程或者缩小其规模的话, 就尽量完善选线的 方案, 使线路的设置避开这些需要进行穿越工程的路段, 减少总工程量的 同时也能减小工程的难度。

\section{3 蜃房设计}

泵房的结构形式很多, 干室型葲房在日常中应用得较多, 缆车型和 浮船型用的较少。地基在建筑物中起着关键作用, 严禁百房坐落在软基 上获一半土基一半软基, 因此要加强地基的处理, 严防地基出现裂缝破 坏。此外, 单位应重视洜站内各项设备的维修问题, 进行定期检查, 一旦 发现设备出现了问题, 应尽快停止运行, 着手安排维修, 如果设备已经老 化, 则需要增加投入, 更换新的设备, 尤其是水泵、电动机这些主要设备, 更要加强监管。

\section{4 结语}

在具体管道设计中, 应根据工程规模, 管道工作压力, 输水距离, 沿线 地形地质情况等, 进行技术、经济、安全等方面综合比较论证后, 选择最佳 输水线路及管材, 这对保障长距离输水管道输水效果, 充分发挥其供水优 势具有重要意义。

\section{[参考文献]}

[1]叶永,谢作为,罗威.农村长距离输水管道设计 [J].中国高新科 技,2017,1(04):22-24.

[2]周琼.农村长距离柔性接口输水管线试压施工技术简介[J]. 安 装,2017,(01):56-57.

[3]戴萍.农村长距离输水管道工程设计问题探讨 [J]. 中国设备工 程,2017,(24):168-169. 